\title{
A note from the editors
}

\author{
Klaus Hoeffken ${ }^{1} \cdot$ Laura Walsh $^{2}$
}

Published online: 7 January 2021

(c) The Author(s), under exclusive licence to Springer-Verlag GmbH, DE part of Springer Nature 2021

What an ambivalent year that is going to end!

The deadly virus is holding the world by ransom since the beginning of 2020. In contrast to the comparable Spanish influenza H1N1 virus of 1918, deadly to the young and middle aged, SARS CoV-2 is deadly to the old, very old and cancer patients.

Numerous publications have shown that older cancer patients-whether immune-compromised or not-are very vulnerable and prone to the COVID-19 infection. Thus, patients - and the medical staff caring for them — have been infected despite stringent hygiene plans, postponing of nonessential and non-vital diagnostic or therapeutic measures. Moreover, patients stayed at home because of increased anxiety of contracting the virus, thus risking progression of their cancer.

Now, there is light at the end of the tunnel: the vaccines.

Most interestingly, besides the traditional production of devitalized virus vaccine, a completely new vaccine containing virus protein mRNA - initially designed to immunize cancer patients against their own cancer-has given very promising phase 3-results and is now being released by the authorities.

The other side of the coin has been for our journal a tremendous increase in acceptance by the scientific community. Due to quarantine or lockdowns, scientist all over the world have used the time to write original papers or perform literature reviews and meta-analyses. This productivity has resulted in a 50\% increase submissions ( $>4500$ as compared to 3000 in 2019). Simultaneously, the metrics of our journal have again increased (2019 Impact Factor 3.673 $\cdots 2018$ Impact Factor 3.486 ․2017 Impact Factor 3.377).

Taking into account this increase in the workload for the editors and the editorial office, we introduce and very warmly welcome Florian Lordick, medical oncologist and head of the Comprehensive Cancer Center at the University of Leipzig Medical School, as deputy editor. Professor Lordick is a long-standing member of our editorial board and was editor-in-chief of the "Forum", the official journal of the German Cancer Society, until the end of 2020. He has accepted to serve as deputy editor for our journal, the official journal of the German Cancer Society (formerly "Zeitschrift Krebsforschung” founded in 1906) as of January 2021.

In summary, we look back at an ambivalent year and look forward to a brighter 2021.

We thank all the authors for their faithfulness, our readers for their loyalty and wish all a healthy and happy New Year.

\section{Compliance with ethical standards}

Conflict of interest None.

Publisher's Note Springer Nature remains neutral with regard to jurisdictional claims in published maps and institutional affiliations.
Klaus Hoeffken

hoeffken.editor@gmail.com

Laura Walsh

Laura.Walsh@springer.com

Berlin, Germany

2 New York, USA 